\title{
Determinants of Elderly Behavior Follow the Posyandu in the Working Area of Kebonsari Primary Healthcare Surabaya
}

\section{Made Ariani}

Departement Of Health Promotion And Behavioral Science, Faculty Of Public Health, Universitas Airlangga, Surabaya Indonesia

Email: made.ariani-2016@fkm.unair.ac.id

\begin{abstract}
Background: Indonesia is ranked $4^{\text {th }}$ in the World with the largest population in 2017 of 261,890,882 million. According to the 2017 Central Bureau of Statistics, the elderly population is 23.4 million (8.97\%) of the Indonesian population. The habit of the elderly attending the Integrated Health Center (Posyandu) can have a good impact on the health of the elderly in the future. Objective: The aims of this study was to analyze the factors associated with the participation of the elderly following the Posyandu. Method: This study used Cross Sectional design with a sample of 210 respondents aged 45-59 years; 6074 years; 75-84 years; and >84 years old. The technique used in sampling is simple random sampling with its independent variables namely intention, social support, information access, personal autonomy, and action situations in the elderly. The dependent variable is the activity of the elderly following the Posyandu. The data collection technique used primary data and secondary data. Data were analyzed by the chi square test through the SPSS application to see factors related to the activity of the elderly following the Posyandu. Result: From the results of the analysis, all independent variables showed a relationship between the independent variables on the activity of the elderly in attending the Elderly Posyandu $(P<\alpha(\alpha=0.05))$. The $P$ value for each variable, namely the intention $P$ value $=0.015(R P$ 3.619: $95 \% \mathrm{Cl}$ 1.599-8.188); social support $P$ value $=0.008(R P$ 2.374: $95 \% \mathrm{Cl} 1.285-4.385)$; access to information $P$ value $=0.007(R P$ 2,714: $95 \% \mathrm{Cl} 1.356-5.429)$; personal autonomy $P$ value $=0.012(R P 2.876: 95 \% \mathrm{Cl} 1.316-6.289)$; and the action situation $P$ value $=0.0001(R P$ 5.575: $95 \% \mathrm{Cl}$ 2.913-10672). Elderly people with supportive action situations tend to actively participate in Posyandu 5 times greater than the elderly with non-supportive action situations. Conclusion: there is a significant relationship between intention, social support, information access, personal autonomy, and the situation of the elderly's actions towards the active participation of the elderly in the Posyandu.
\end{abstract}

Keywords: Activeness, Elderly, Posyandu

\section{INTRODUCTION}

The success of national development in Indonesia is measured from the Human Development Index (HDI) of the economic side with per capita income, the education side with literacy rates, and the last from the health side with life expectancy. The more prosperity of a country, the increasing life expectancy of the population so that it causes the number of elderly population from year to year to increase.

According to the Central Statistics Agency (BPS) in 2017, the population of Indonesia is increasing year by year, especially in the population in the Elderly Group (Elderly) reaching more than $7 \%$. In 2013 alone the number of elderly population in Indonesia who were aged 60 years or more was ranked 108th of all countries in the world. Whereas in 2020 the number of elderly people in Indonesia is predicted to increase to 28 million people with more than 71 years of age (Badan Pusat Statistik Indonesia, 2018).

The size of the elderly population in Indonesia in the future will have both positive and negative impacts. Positive impact is called if the elderly are in a healthy, active and productive state. While the negative impact if a large number of elderly people have a problem of declining health resulting in an increase in the cost of health services, decreased income and productivity, increased disability and the lack of social 
support and environment friendly to the elderly (Kementerian Kesehatan RI, 2014). Health Act No. 36 of 2009 article 138 states that the Government is obliged to guarantee the availability of health facilities and services as an effort to maintain health for the elderly to keep them healthy and productive socially and economically in accordance with human dignity (Departemen Kesehatan Republik Indonesia, 2009). Government efforts to deal with problems that occur in the elderly are regulated in the Minister of Health Regulation of the Republic of Indonesia (Permenkes RI) No. 67 of 2015 concerning the Implementation of Aging Health Services in Primary Health Care (Puskesmas) (Kementerian Kesehatan RI, 2015).

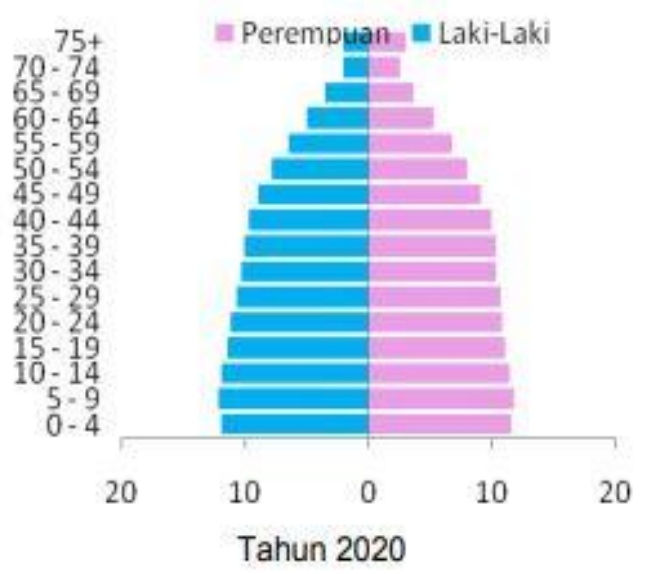

Source: UNFPA Indonesia Monograph, 2014 Figure 1. Projected Population of the Elderly Population in Indonesia in 2020

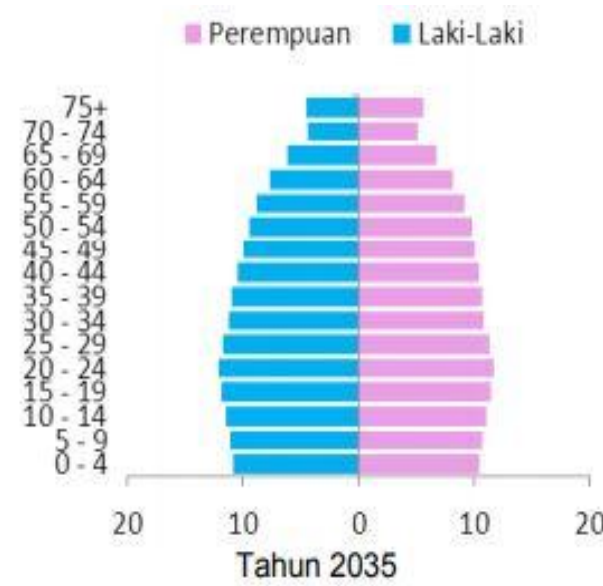

Source: UNFPA Indonesia Monograph, 2014 Figure 2. Projected Population of the Elderly Population in Indonesia in 2035

In the city of Surabaya, besides referring to the Regulation of the Minister of Health of the Republic of Indonesia
(Permenkes RI) number 67 of 2015 in its implementation regulated in Surabaya Mayor Regulation number 33 of 2012 concerning the implementation of Supplementary Feeding (PMT) for the elderly (Walikota Surabaya, 2012; Kementerian Kesehatan RI, 2015). In the management of supplementary feeding (PMT) activities for the elderly, it is carried out 4 (four) times a month, which is once done in conjunction with the elderly posyandu activities such as examination of abdominal circumference, weight, height, tension, GDA (Random Blood Sugar), medicine according to doctor's indication, and health education. The next three times every week a pure supplementary feeding (PMT) is carried out.

Table 1. Distribution of Number of Posyandu Elderly in the City of Surabaya in 2010-2016

\begin{tabular}{cc}
\hline Year & Number of Posyandu for Elderly \\
\hline 2010 & 278 \\
2011 & 415 \\
2012 & 464 \\
2013 & 557 \\
2014 & 601 \\
2015 & 675 \\
2016 & 668 \\
\hline \multicolumn{2}{c}{ Source: Surabaya City Health Office Annual } \\
\multicolumn{2}{c}{ Report 2016 }
\end{tabular}

A research study conducted at the Medaeng Waru Sidoarjo Community Health Center in 2015 found that degenerative diseases including hypertension, diabetes mellitus, high cholesterol, and myalgia occurred in the region. With the aspect of Social Capital, namely trust, social networks, and norms, it makes the Elderly in the area become active in the activities of the Elderly Posyandu to control their body condition against the degenerative diseases they suffer (Burhanuddin, 2016).

The results of a preliminary study conducted in a previous study conducted at one of the Posyandu in the working area of the Kebonsari Public Health Center in Surabaya found that there were still those who had not routinely exercised the elderly which were held at the time of the elderly Posyandu (Pratiwi and Hatmanti, 2015). Even though elderly exercise is one of the routine activities carried out during the posyandu. So that the elderly Posyandu activities organized 
by the Kebonsari Health Center are not running optimally.

Based on the explanation above it can be seen that the determinant of the behavior of the elderly is related to the activeness of the elderly following the Posyandu of the elderly in the working area of the Kebonsari Health Center in Surabaya. The purpose of this study was to analyze the determinants of elderly behavior based on the theory of Snehandu B.Karr relating to the activeness of the elderly following the posyandu in the work area of the Kebonsari Primary Health Care in Surabaya.

\section{METHOD}

This research was an analytic observational research, with a cross sectional design. The sample selection used simple random sampling taken from 840 elderly who become permanent members in 10 posyandu and as many as 210 samples obtained by the WHO according to the age of the elderly are 4559 years (middle age); 60-74 years old (old age); 75-84 years (old age); and > 84 years (very old age). Data collection techniques used were primary data and secondary data. Primary data were obtained from the observation of the activeness of the elderly when the posyandu took place and the distribution of questionnaires containing the variables studied, namely intention, social support, access to information, personal autonomy, and the situation of action. Secondary data were obtained from the Health Profile of the Puskesmas in 2017, the attendance list, and the Card Towards Health (KMS) of the elderly who attended the posyandu for a year.

The analysis technique used in this study was to analyze the independent variables in the elderly related to the activeness of the elderly following the posyandu using the chi-square test through the SPSS application. Then the frequency distribution or percentage (\%) form of each table was reported as an analysis result.

\section{RESULTS AND DISCUSSION}

The results of research conducted at the elderly Posyandu in the working area of Kebonsari Surabaya Health Center through questionnaires and observation of activities in each elderly Posyandu.

Table 2 presents the results of the study based on the characteristics of the elderly. The majority of elderly female respondents were $62.4 \%$ aged $60-74$ years, namely $42.9 \%$ (old age). The elderly graduated from high school by $41 \%$ and the elderly did not work as much as $65.2 \%$.

Table 2. Characteristics of Respondents by Gender, Age, Education, and Occupation

\begin{tabular}{lll}
\hline \multicolumn{1}{c}{ Characteristics } & $\mathbf{n}$ & $\%$ \\
\hline Gender & & \\
\hline Male & 79 & 37.6 \\
Female & 131 & 62.4 \\
\hline Age & & \\
\hline $45-59$ year & 14 & 6.7 \\
60-74 year & 90 & 42.9 \\
75-84 year & 78 & 37.1 \\
$>84$ year & 28 & 13.3 \\
\hline Education & & \\
\hline Uneducated & 15 & 7.1 \\
Graduated from & 49 & 23.3 \\
Elementary School & & \\
Graduated from Junior & 39 & 18.6 \\
High School & & \\
Graduated from Senior & 86 & 41 \\
High School & & \\
College & 21 & 10 \\
\hline Employment Status & & \\
\hline Employed & 137 & 65.2 \\
Unemployed & 16 & 7.6 \\
Retired & 57 & 27.1 \\
\hline Total & 210 & 100 \\
\hline
\end{tabular}

Table 3. Distribution of Frequency of Elderly Activities Following the Elderly Posyandu at the Kebonsari Health Center in Surabaya 2019

\begin{tabular}{|c|c|c|}
\hline $\begin{array}{l}\text { Participation in } \\
\text { Posyandu }\end{array}$ & $n$ & $\%$ \\
\hline Active & 151 & 71,9 \\
\hline Not Active & 59 & 28,1 \\
\hline
\end{tabular}

Table 3 shows that most of the elderly actively participate in the Posyandu for the elderly, which is held every month at $71.9 \%$. The activeness of the elderly following this posyandu is based on the presence of the elderly every month when attending the elderly posyandu through the KMS Lansia (Card Towards Health) and a list of elderly attendance that is managed by local Posyandu cadres. The Posyandu for the elderly in the working area of the Surabaya Kebonsari Community Health 
Center in terms of the number of Posyandu formed from year to year has indeed increased. But in reality there are still elderly people whose activeness to participate in elderly Posyandu is still lacking. This was obtained from previous research that there are still many elderly people who do not take part in the elderly gymnastic activities routinely. Even though one of the elderly posyandu activities include elderly exercise which is beneficial for the health of the elderly.

Good attendance or active participation in activities at the elderly posyandu if the frequency of attendances 6 times per year, while the presence of a bad or inactive presence if the frequency of attendance $<6$ times per year (Kementerian Kesehatan RI, 2014).

Table 4. Relationship Between Intentions, Social Support, Access to Information, Personal Autonomy, and Action Situations towards Elderly Activities Following the Posyandu for the Elderly in the Work Area of Kebonsari Surabaya Health Center in 2019

\begin{tabular}{|c|c|c|c|c|c|}
\hline \multirow{2}{*}{$\begin{array}{l}\text { Independent } \\
\text { Variable }\end{array}$} & \multicolumn{2}{|c|}{ Activity of the Elderly } & \multirow[b]{2}{*}{$\begin{array}{c}P \text { value } \\
(\alpha=0,05)\end{array}$} & \multirow{2}{*}{$\begin{array}{c}\text { Ratio } \\
\text { Prevalence } \\
\text { (RP) }\end{array}$} & \multirow{2}{*}{$\begin{array}{l}\text { Confident } \\
\text { Interval } \\
\text { (CI) }\end{array}$} \\
\hline & Active (\%) & $\begin{array}{c}\text { Not } \\
\text { Active (\%) }\end{array}$ & & & \\
\hline \multicolumn{6}{|c|}{ Behavior Intention } \\
\hline $\begin{array}{l}\text { High } \\
\text { Low }\end{array}$ & $\begin{array}{l}65.7 \\
6.2\end{array}$ & $\begin{array}{l}21 \\
7.1\end{array}$ & 0.015 & 3.619 & $1.599-8.188$ \\
\hline \multicolumn{6}{|l|}{ Social Support } \\
\hline $\begin{array}{l}\text { High } \\
\text { Low }\end{array}$ & $\begin{array}{l}45.7 \\
26,2\end{array}$ & $\begin{array}{l}16,2 \\
11,9\end{array}$ & 0,008 & 2,374 & $1,285-4,385$ \\
\hline \multicolumn{6}{|c|}{ Access Information } \\
\hline $\begin{array}{l}\text { High } \\
\text { Low }\end{array}$ & $\begin{array}{l}60,5 \\
11,4\end{array}$ & $\begin{array}{l}18,5 \\
9,6\end{array}$ & 0,007 & 2,714 & $1,356-5,429$ \\
\hline \multicolumn{6}{|c|}{ Autonomy Personal } \\
\hline $\begin{array}{l}\text { High } \\
\text { Low }\end{array}$ & $\begin{array}{l}64,3 \\
7,6\end{array}$ & $\begin{array}{l}21 \\
7,1\end{array}$ & 0,012 & 2,876 & $1,316-6,289$ \\
\hline \multicolumn{6}{|l|}{ Action Situation } \\
\hline $\begin{array}{l}\text { High } \\
\text { Low }\end{array}$ & $\begin{array}{l}54,3 \\
17,6\end{array}$ & $\begin{array}{l}10 \\
18,1\end{array}$ & 0,0001 & 5,575 & $2,913-10,672$ \\
\hline
\end{tabular}

Table 4 presents the relationships between variables. Bivariate analysis used the chi square test to find out the relationship between the activeness of the elderly following the elderly posyandu and the determinants of elderly behavior based on Snehandu B. Karr's theory in the work area of the Kebonsari Public Health Center in Surabaya. Research from the bivariate analysis based on Table 4 found significant results, each having a relationship between behavioral factors based on the theory of Snehandu B. Karr with the activeness of the elderly following the elderly Posyandu.

It is known that there is a significant relationship between the intention of the respondents and the activeness of the elderly to participate in the elderly posyandu. The results showed that elderly who had high intentions by $65.7 \%$ were more active in participating in the Posyandu Elderly. As many as $21 \%$ of the elderly despite having high intention turned out to be not actively participating in the Posyandu held every month. Based on the value of the RP (Ratio Prevalence) on the intention variable towards the activeness of the elderly following the posyandu of 3,619. This means that elderly with high intentions have a tendency to actively participate in posyandu activities by 3.619 or 3 times greater than those with low intention (95\% Cl 1.599-8.188).

Significant relationships were obtained from social support in the elderly. Most respondents who received high social support were actively participating in the elderly Posyandu at $45.7 \%$, while low social support at $16.2 \%$ were not actively following the Posyandu for the elderly. Even though the elderly get high social support, the elderly are not necessarily active in joining the Posyandu. The RP value for this variable is 2.337, meaning that the elderly with high social support tend to actively participate in posyandu activities at 2,374 or 2 times greater than the elderly with low social support $(95 \% \mathrm{Cl} 1.285-4.385)$. 
There is a relationship or link between information access and the activeness of the elderly to join the elderly posyandu in the work area of the Kebonsari Public Health Center in Surabaya. As many as $60.5 \%$ of the elderly get information about posyandu which causes the elderly to become active in joining the Posyandu activities every month. RP value on the information access variable is 2.714 . This means that the access to information obtained by the elderly tends to actively participate in posyandu at 2.714 or 2 times greater than those who do not get access to information (95\% Cl 1.356-5.429).

A significant relationship is also obtained from personal autonomy in the elderly. More than half of the elderly who have independent personal autonomy of $64.3 \%$ are more active in participating in the elderly posyandu activities in the work area of the Kebonsari Public Health Center in Surabaya. The value of RP in the independent personal autonomy variable has a tendency to actively participate in posyandu at 2.876 which means that it is 2 times greater than the elderly who are not independent $(95 \% \mathrm{Cl} 1.316-6,289)$.

Significant correlation was obtained from the elderly who have a good supportive action situation of $54.3 \%$ following the posyandu for the elderly in the active category. While the elderly who have situations that do not support action are in the inactive category at $18.1 \%$. For the action situation variable has a RP value of 5.575 . This means that the action situation variable that supports the elderly has a tendency to join the posyandu for the elderly 5 times greater than the situation of the elderly action that does not support it. It can also be assumed that the supportive action situation in the elderly has a greater tendency to be active in the posyandu activities of the elderly compared to other factors (95\% Cl 2.913-10.672).

\section{Intention}

The intention of the elderly in this study is the desire possessed by the elderly to take part in the elderly posyandu activities routinely every month. The best way to find out someone's desire to do something related to their health is to know what their intentions are (Jatmika, 2015).
Based on the results of existing studies, the majority of the elderly have a high intention to attend the posyandu for the elderly. It can be assumed that the intention of the elderly to join the posyandu of the elderly is quite good where the elderly still want themselves to stay healthy even at a young age.

In line with previous research which states that the intention of the elderly to continue to follow the elderly Posyandu at the health center and the ability to always come in the elderly Posyandu activities even though no one is accompanying. In addition, the elderly who intend to participate in posyandu are obtained from the elderly who have a view that strongly agrees on trust, object evaluation, motivation to follow behavior, control of trust, and feel the strength of participation in following the elderly Posyandu (Retno, 2016).

\section{Social Support}

Social support basically describes the role or influence that can be caused by other significant people such as family, peers, relatives, and people in other surrounding environments. The aspects of social support according include:

1. Emotional support includes expressions of sympathy, empathy, caring, and attention to those concerned

2. Appreciation support includes expressions of respect or respect for positive actions for the person

3. Instrumental support includes direct assistance to facilitate the behavior concerned such as delivering to the destination, taking time, giving objects that support healthy behavior and others

4. Informative support includes giving advice, suggestions and feedback (Melianawati, 2015).

Based on the results of research that has been done most of the elderly argue that they have high social support. Elderly who get high social support include actively taking part in the elderly posyandu routinely. This is not in line with previous research which states that the activeness of the elderly in joining the elderly posyandu is not related to social support provided by families, posyandu cadres, peers or community leaders around the elderly environment. 


\section{Information Access}

Access to information is a convenience given to someone or the public to obtain public information as needed. Sources of information are obtained by using telecommunication tools and through channels or other media. Access to information needs is recognized as a basic right for everyone, but there is a gap in society, namely between people who have more access to information and people who lack access to information.

Based on the results of the study most of the respondents stated that there was access to information about the elderly Posyandu in the neighborhood around the Elderly and actively participated in the Posyandu Elderly. In line with previous research, it is known that the elderly experience better changes regarding their health by routinely attending posyandu activities (Manihuruk and Nadjib, 2018). Perceived needs in utilizing posyandu are obtaining information on health conditions, exchanging friendships with fellow elderly, obtaining health services easily, being able to increase knowledge through counseling obtained from health workers, knowing the threat of diseases that can be suffered by the elderly at an early stage.

\section{Personal Autonomy}

Autonomy is defined as the individual as the initiator and source of behavior (Guay, Ratelle and Chanal, 2008). Supporting autonomy also means taking an individual perspective, giving choices, and giving reasons if there are no other possible choices (Filak and Sheldon, 2003).

Based on the results of the study, the elderly declared independence in their personal autonomy. This can be interpreted that most of the elderly are in healthy condition so that they can make decisions and act according to their personal decisions without the need for coercion from others relating to their health. The elderly are independent because they are in good health. With a healthy condition, the elderly are able to do any activity without asking for help from others, or as little as possible depends on others. While the elderly who are not independent, must be assisted even not able to do daily activities.
Elderly who are not independent due to physical conditions that have declined due to the aging process, and the illness suffered by respondents causes respondents to need help from others in carrying out activities.

In line with the results of previous studies suggested that independence arising at the age of age that is supported by good socioeconomic, high family support can cause the elderly to achieve happiness physically and mentally or achieve well-being (Wiliyanarti, 2017).

\section{Action Situation}

The theory put forward by Snehandu B. Karr that the Situation of Action is a certain condition that encourages a person to behave or not behave for his health. The situation of the condition in question is very broad including geographical conditions, facilities available in the place of health services in this case is a place Posyandu, as well as the ability possessed by the elderly themselves to come to reach the Posyandu for the elderly.

The situation of action on the elderly in this study includes distance, time taken, costs incurred, weakness of the elderly body when attending the Posyandu Elderly and how the comfort and security of the conditions in which the posyandu is held in each region. Based on the results of the research that has been done, it is found that the respondents surveyed have a supportive action situation in terms of the geographical condition of the environment around the elderly to attend the Posyandu Seniors.

Previous research suggests that elderly are actually active in the use of elderly Posyandu (Rusmin, Bujawati and Habiba, 2017). Because the elderly assume, even though they incur a transportation fee of more than Rp. 10,000 , it is not comparable with the benefits that are obtained if they routinely attend Posyandu activities. This is in line with previous research, the elderly assume that by following the Posyandu the elderly can generate benefits for themselves. If the elderly already know the benefits of the elderly posyandu then even when the elderly are experiencing physical complaints, they remain active in following the elderly posyandu (Retno, 2016). 
This study contrasts with the results of previous study in Kebumen, where many elderly people who do not actively visit the posyandu for the elderly are due to seeing the physical condition of the elderly. The other reason for the elderly is because the elderly routinely check their health condition in the hospital (Barokah, 2016).

\section{CONCLUSIONS}

Based on the results of the research that has been done, it is concluded that there is a significant relationship between intention, social support, access to information, personal autonomy, and the situation of the elderly's actions towards the activeness of the elderly following the elderly Posyandu in the work area of the Kebonsari Public Health Center in Surabaya.

\section{REFERENCES}

Badan Pusat Statistik Indonesia (2018) 'Statistik Lingkungan Hidup Indonesia'.

Barokah, S. (2016) Faktor-faktor yang Mempengaruhi Pemanfaatan Posyandu Lansia di Desa Tanjungmeru Kecamatan Kutowinangun Kabupaten Kebumen. STIKES Muhammadiyah Gombong.

Burhanuddin, A. (2016) Aspects of Social Capital Against the Participation of the Elderly Community in the Visit of Elderly Posyandu in the Medaeng Waru Health Center Area. Universitas Airlangga.

Departemen Kesehatan Republik Indonesia (2009) Undang-undang Republik Indonesia Nomor 36 Tahun 2009 tentang Kesehatan. Jakarta.

Filak, V. F. and Sheldon, K. M. (2003) 'Student psychological need satisfaction and college teachercourse evaluations', Educational Psychology, 23(3), pp. 235-247. doi: https://doi.org/10.1080/01443410320 00060084.

Guay, F., Ratelle, C. F. and Chanal, J. (2008) 'Optimal learning in optimal contexts: The role of selfdetermination in education.', Canadian Psychology/Psychologie canadienne. Guay, Frédéric: Departement des fondements et pratiques en education, Faculte des sciences de l'education, Universite Laval, Ste-Foy, PQ, Canada, G1K 7P4, Frederic.Guay@fse.ulaval.ca:

Educational Publishing Foundation, 49(3), pp. 233-240. doi: $10.1037 / \mathrm{a} 0012758$.

Jatmika, S. E. D. (2015) 'Norma Masyakarat Untuk Meningkatkan Niat Ibu Hamil dalam Memberikan ASI Eksklusif', Jurnal Kesehatan "Samodra Ilmu", 6(1), pp. 50-57.

Kementerian Kesehatan RI (2014) Infodatin-Lansia.2014.Pdf. Jakarta: Pusat Data dan Informasi Kementerian Kesehatan RI.

Kementerian Kesehatan RI (2015) 'Peraturan Menteri Kesehatan Republik Indonesia Nomor 67 Tahun 2015 tentang Penyelenggaraan Pelayanan Kesehatan Lanjut Usia di Pusat Kesehatan Masyarakat'. Jakarta.

Manihuruk, M. and Nadjib, M. (2018) 'Faktor-faktor yang Berhubungan dengan Kunjungan Lansia ke Posbindu Lansia di Wilayah Kerja Puskesmas Kelurahan Bintara Kota Bekasi Tahun 2017', Jurnal Kebijakan Kesehatan Indonesia : JKKI, 7(4), pp. 158-167. doi: $10.22146 / J K K I .26409$.

Melianawati (2015) 'Hubungan antara dukungan sosial orang tua dengan minat melanjutkan pendidikan perguruan tinggi pada remaja di kecamatan keluang Musi Banyuasin', Jurnal Psikologi Universitas Bina Darma Palembang, 1(1), pp. 1-11.

Pratiwi, D. and Hatmanti, N. M. (2015) 'Senam Lansia Mempengaruhi Tekanan Darah Lansia Di Puskesmas Kebonsari Surabaya', Journal of Health Sciences, 6(2). doi: 10.33086/jhs.v6i2.40.

Retno, D. M. (2016) 'Pengaruh Niat Terhadap Keaktifan Lansia Dalam Mengikuti Posyandi Lansia di Puskesmas Kalijudan, Surabaya', Jurnal Ilmiah Kebidanan, 3(1), pp. 6069.

Rusmin, M., Bujawati, E. and Habiba, N. (2017) 'Faktor - Faktor Yang Berhubungan Dengan Pemanfaatan Posyandu Lansia Di Wilayah Kerja Puskesmas Somba Opu Kabupaten Gowa Tahun 2015', Al-Sihah Public Health Journal, 9(1), pp. 9-18.

Walikota Surabaya (2012) 'Peraturan Walikota Surabaya Nomor 33 Tahun 
86 Jurnal Promkes: The Indonesian Journal of Health Promotion and Health Education Vol. 8 No. 1 Maret 2020 : 79-86, doi: 10.20473/jpk.V8.11.2020.79-86

2012 tentang Penyelenggaraan Pemberian Makanan Tambahan bagi Lansia'. Surabaya: Walikota Surabaya.

Indikator dan Indeks Kesejahteraan

Wiliyanarti, P. F. (2017) Pengembangan Lanjut Usia di Surabaya. Universitas Airlangga. 